\title{
STUDY OF THE NON-ACOUSTIC STAPEDIUS REFLEX \\ ELICITED BY ELECTROCUTANEOUS STIMULATION
}

\author{
KAZUHIRO HOHJYO \\ Department of Otolaryngology, Niigata University School of Medicine, Niigata \\ (Director: H. Ino, M. D.)
}

\begin{abstract}
The purpose of this study is to describe reflex contraction of the stapedius muscle elicited by unilateral electrical stimulation of the skin in the external auditory canal.

The reflex of the stapedius muscle was recorded by an impedance meter (Madsen 20 70) and a level recorder.

The electrocutaneous stimulation caused no impedance change in patients with unilateral peripheral facial palsy involving the stapedius muscle and with otosclerosis verified by operation. It could be concluded that the impedance change is the result of reflex contraction of the stapedius muscle elicited by electrocutaneous stimulation in the external auditory canal.

In normal ears, various stimulus parameters were studied with special reference to the reproducibility and the habituation on their effects. Also, special care was taken not to cause discomfort on the patient. The discomfort and the habituation were depends on the frequency and width of the stimulating pulses.

The results indicate that an appropiate electrical stimulus was the pulses with $0.01 \mathrm{msec}$ width discharged at a rate of $25 \mathrm{~Hz}$.

The electrocutaneous stimulation in the external auditory canal caused bilateral stapedius reflexes. The size of the stapedius muscle contraction elicited by contralateral stimulation was, however, smaller than that elicited by ipsilateral stimulation.
\end{abstract}

$\mathrm{A} 82-0689-22522$

\section{外耳道電気刺激による非音響性アブミ骨筋反射の研究}

\author{
新潟大学医学部耳鼻咽喉科学教室（主任：猪 初男教授） \\ 北橴 和 博
}

\section{I 緒 言}

インピーダンスメータの発達によりヒトのアブミ骨筋 反射の澌定が，間接的かつ容易に教こなわれるようにな

り，中耳伝音系の診断ならびに神経耳科学的立場加ら臨 床上ますます重要な検查法になりつつある、アブミ骨筋 反射を惹起させる方法として音刺激が通常使用されて和

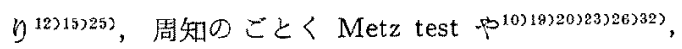

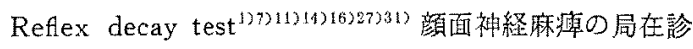

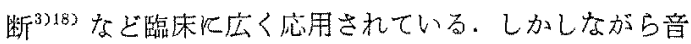

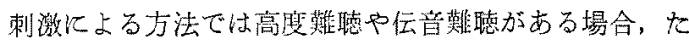
とえアブミ骨筋が正常な機能を持っていても筋反射を起 こすに充分な刺激量汇達せず筋反射を㮢出することが困 難なことも少なくない，一方，アブミ骨乵は香刺激はかか

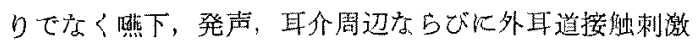


麦 1 外耳道電気刺激条件および測定法

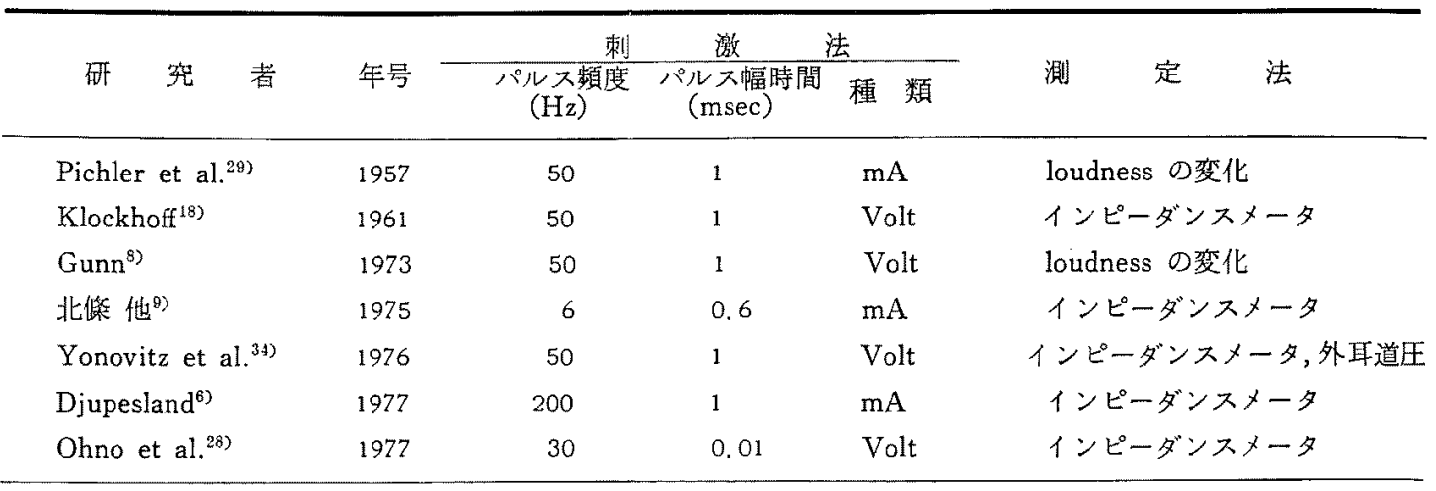

などの非音響性因子によっても収縮するので”非音響性 にアブミ骨筋反射を惹起し，この反射を桧出すること は, 、わ畞るイピーダンスオージオメトリーの分野に とって非常行役立つものと思われる. 非音響刺激として 上卜の場合，外耳道得当な電気刺激定与光る方法が用 いられてきた（表 1）が，臨床へ応用するため江恒常 性, 疼痛轻減等な机改善すべきいくつ加の問題点が残さ れている，そこで著者は，再現性のあるしかも順応現象 の少ない，そして不快感，疼痛の柽微な最適電気刺激条 作を求める目的で実煥を行ない，さらにその刺激条件を 使用して臨床例への忘用を試みたので埌告する。

\section{II 検 查方 法}

1）外耳道插入刺激電極には $3 \times 16 \mathrm{~mm}$ の極めて薄い $\mathrm{Ag} / \mathrm{AgCl}$ 電極を使用した。これ銀板の表面をエメリ 一粉で十分なめらかにみがいてアルコール泩浮し, 生理 食塩水中招いて $0.5 \mathrm{~mA}$ で䄪 5 分聞陽極で電気分解し て表面に $\mathrm{AgCl}$ を付着させた。不関電極としては皿電極 を使用し，それぞれアインレーターに連結した。

2）電気刺激装置として 電子式刺激装置 (SEN-1101 NIHONKOHDEN) 使用しアイソレーター (SS-101J NIHONKOHDEN）飞接続し、これより矩形波定電流 パルスを発生させた。

3）電気刺激炕とむなら筋反射反応を音響性アブミ骨筋 反射測定と同様に、インピーダンスメータ (Madsen ZO 70）により測定しペン菖きオッシログラフ（WI-380TR NIHONKOHDEN) K記録した.ブロックダイアグラ 么は図1に，耳栓抢よび電極は图２に示す

検查前飞被験者の鼓膜, 外耳道安観察し, 特に耳垢等 は十分飞除去を行い，アルコールで脱脂後，被験者をへ
ットに仰臥させ安静を保つように指示する. 次に外耳道 に耳栓ととも電極老插入し, 電極分軟部外耳道後上壁 にあたることを確認した後, バルーンカテーテルのカフ 飞空気を注人して外耳道を密栓し, かつ電極の固定を行

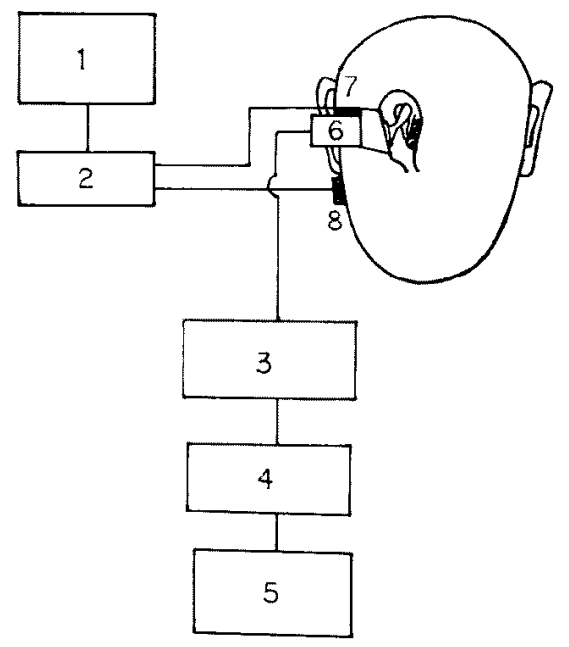

1: Electric stimulator (SEN-1101 NIHOHKOHDEN)

2: Isolotor (SS-101J NIHONKOHDEN)

3: Imbedonce meter (Madsen 2070 )

4: Preamolifier (RDH-2 NIHONKOHDEN)

5: Inkwriting oscillograph (WI-380 TR NIHONKOHDEN)

6: Ear tip

7: Electrode $(+)$

3: Electrode (-)

図 1 ブロックダイアグラム 


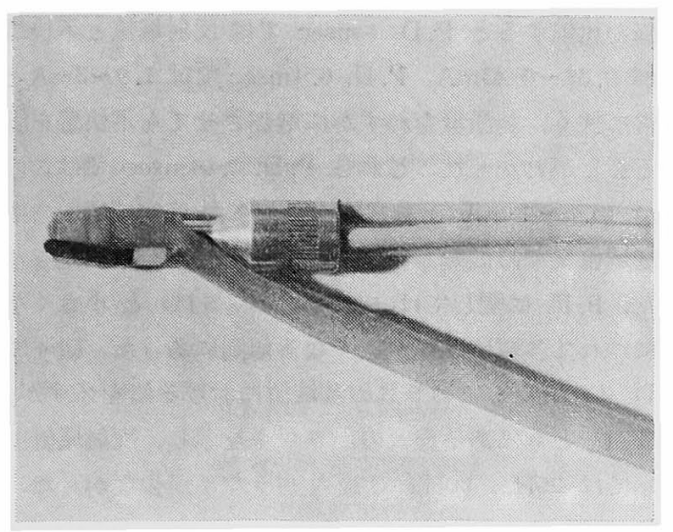

図 2 耳栓拈よび電極

なった. 不関電極は, 刺激側の乳様突起部にアルコール で脱脂後装着した.なお, 刺激電極, 不関電極ともに皮 蔵抵抗を小さくするため電極ノりを使用した．外耳道圧 は鼓膜コンプライアンス曲線がピークを示す点に調節さ

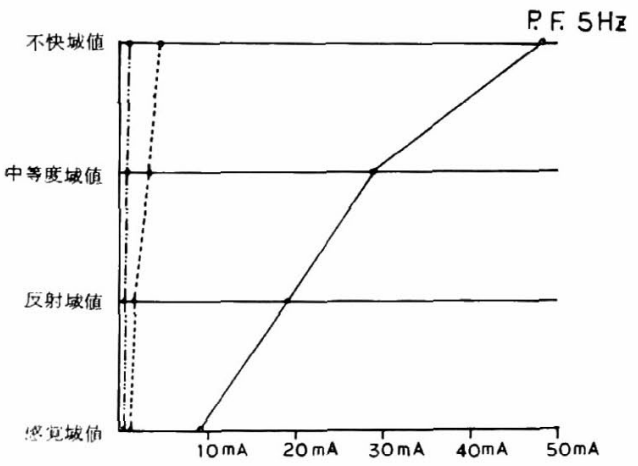

P. $.25 \mathrm{~Hz}$

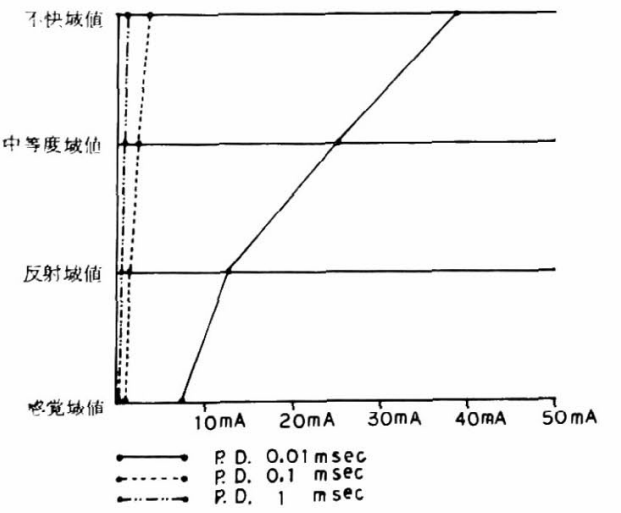

れた.

\section{III 測 定 成 績}

1. 最適刺激条件の探索

耳疾患の既応なく耳鏡所兒掞よび音響性アブミ骨筋反 射に異常の認められない聴力正常 5 耳を対象として次の パラメータについて測定した. すなわち電気刺激として パルス幅時間（以下 P.D. と略す），パルス頻度（以下 P.F. と略す）扣よび電流の強さを種々に設定し，被験 者の不快感, 筋反射反応の振幅, 順応現象との関係汪つ いて検討を行なった．基礎実験とより P.F. 亿関しては $1 \mathrm{~Hz}$ でば於形波刺激 1 個につき 1 反応波形しか得られ なかったが $5 \mathrm{~Hz}$ 以上の刺激では刺激期間中， tonic な 反応波形が認められた. また $100 \mathrm{~Hz}$ 以上飞なると一過 性の phasic な急速比順応を来す反応波形となった. P.D. については短かけれぼ短かいほど疼痛が少なく， $10 \mathrm{msec}$ では筋反射域值飞招いてもかなり不快をともな うことがわかった．以上の結果より P.F.は 50，25，
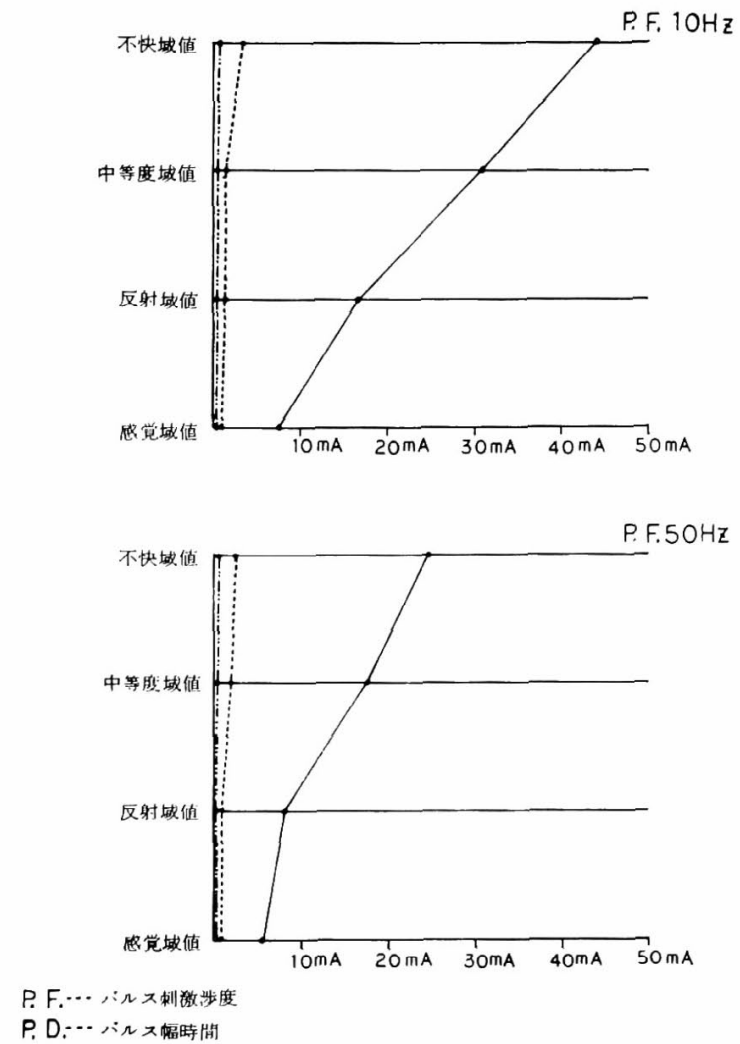

図 3 各条件に括ける各域值の平均 
10, $5 \mathrm{~Hz}$ の4条件, P.D. は 1, 0.1, $0.01 \mathrm{msec}$ の3条 件に設定した。

1) 域值

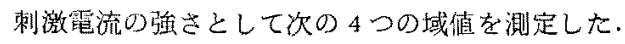

i) 感党域值: 剌湤强度を徐々に市げていっ大時, 外 耳道で最初になでるような刺激希感じる強き。

ii）反射域值：筇区射反応が始ぬて出現する最小判激 强隄。

iii）中等度域值：刺激強度を反射域值以上飞增加して

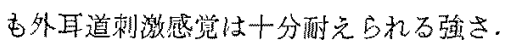

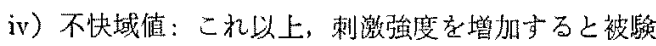
者が不㶧店痛み訴光る強さ。

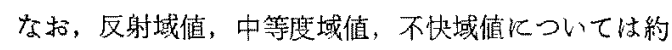
5 梨間隔で 3 回刺激老行い筋反射反応の再現性索確認し た.

結果は图 3 K示すごとく, 各域僨の平均は名 P.F.七 も P.D. が 1，0.1，0.01 $\mathrm{msec}$ と小さくなるにつれて 高くなる傾向にあるが，直線的でない，そして谷域值の
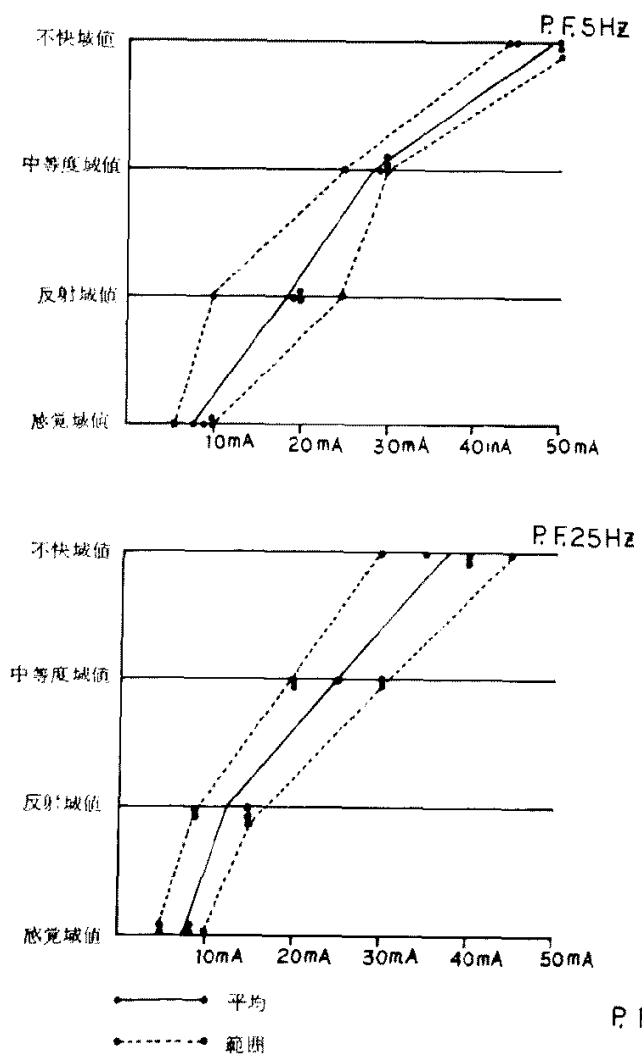

図 4 パルス幅時閏 $0.01 \mathrm{msec}$ での5耳の各域健に和ける优

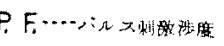

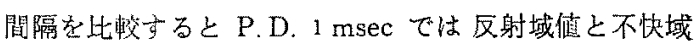
倠が $0.35 \sim 0.43 \mathrm{~mA}$, P.D. 0.1 msec では 1.9 3 $\mathrm{mA}$ 之 非常に狭く，制激量をかずか堌加させても不快感を挀

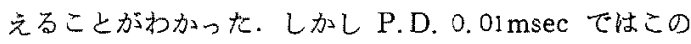
差が 16.6 29mA と非常広広く，末た感覚域值加与中 等度域值までの間隔も $12 \sim 23.4 \mathrm{~mA}$ 亡十分な筙团を示 した.P.F.K閭しては 50，25，10，5 Hz と小さくな

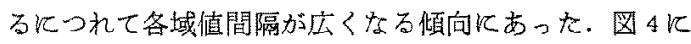
P.D. $0.01 \mathrm{msec} て ゙ の 5$ 耳の备域做に和ける値を示吉加, 各P.F，とも沉ある程度のバラッキを示し，反射域值に 関しては $25 \mathrm{~Hz}, 50 \mathrm{~Hz} て ゙$ 最もバラッキが少なかった。

2) 振幅

全ての刺激条件で電気刺激強淁增加に伴い，反心振幅 の增大傾向を示すが，刺激強度をある程度以上に增加し

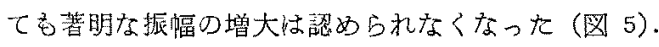
各桻激条件に和ける反的域值，中等度域值招よび不饥域 值での反応振䒇を比较するために，記録波班の最初の立 ち上りを基線上り $\mathrm{mm}$ 貺定した. 図6 亿各刺激条件で
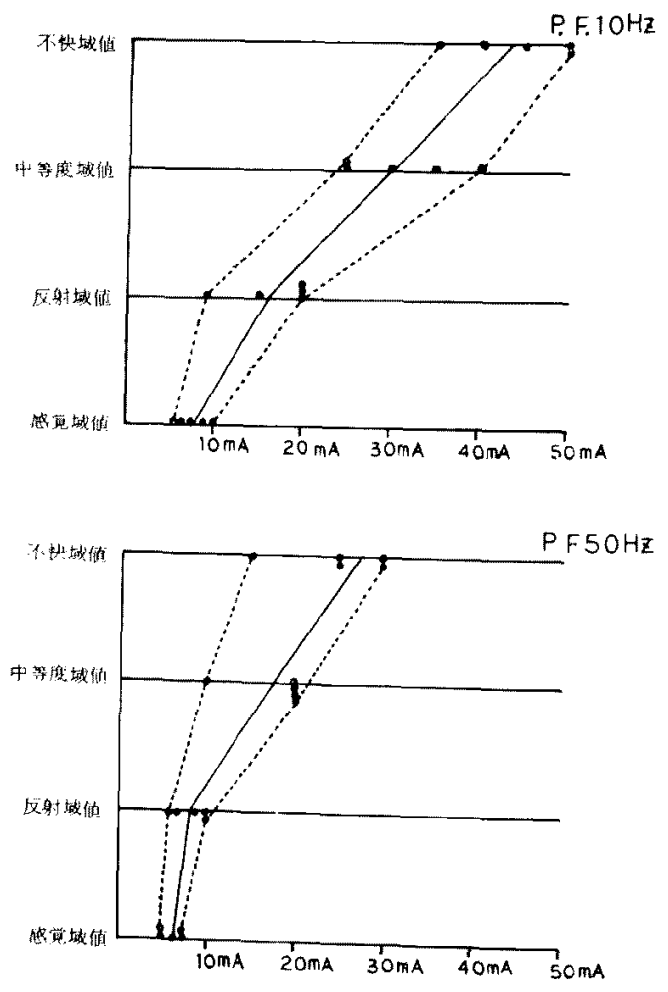

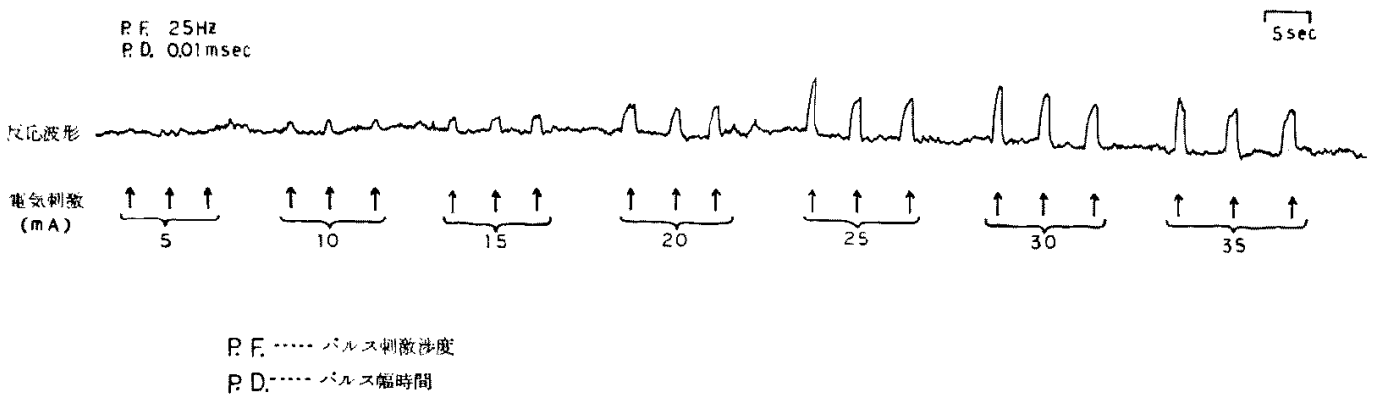

図 5 外耳道電氮刺激によるアブミ骨筋反射反灾波北，10mAで明らかな反心が 認められる。
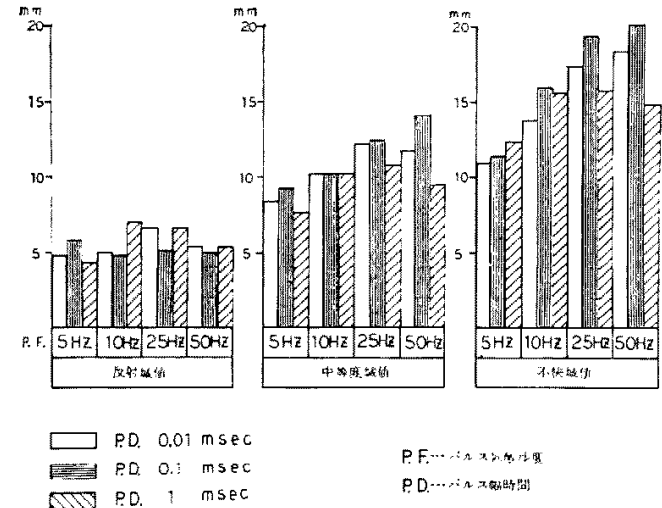

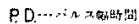

図6 各刺激条件に祘ける各域値の平均反 応振幅の比較

の平均振幅を示す。㴬域值，中等度域值扣上び不快域 值と剌激強度の增加儿伴ない振幅の增大傾向を認める が，中等度域值および不快域值では P.F. $25 \mathrm{~Hz}, 50 \mathrm{~Hz}$, P.D. $0.01 \mathrm{msec}, 0.1 \mathrm{msec} て ゙$ 他の剩激条件上り大きな振 幅が得られた。

3) 㮌灾現䝿

P.D. $0.01 \mathrm{msec}$ Kついて P.F. と順応現象との閣係

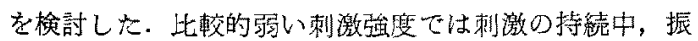
幅の減衰いかける順応現象が認められることが文献”る りはっきりしているため不快域值に就ける10秒間の刺激 に抹いて初期振幅々10秒後の振幅を各々のP.F. Kつい て\%で求めた。その結果，P.F. $50,25,10,5 \mathrm{~Hz}$ て 各平均 $10,83,64,27 \%$ 值加得 られ，P.F. $25 \mathrm{~Hz}$ の

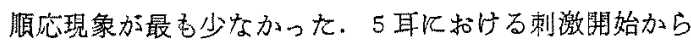
5 秒後，10秒後の振幅の隇衰の程度を図 7 に示した.

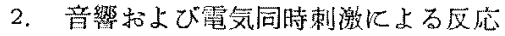

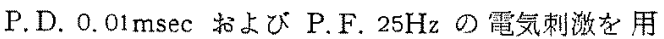
い, 反対側耳より $1 \mathrm{kHz}$ の音刺激を同時飞与え，次の組 合枝で測定を行なった。

a) 域值下音響刺激と域值下電気刺激

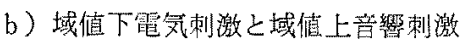

c) 域值上電気刺激と域值下音響刺激

d) 域值上電気刺激之域值上音響刺游

結果は図 8 K示す 電気刺激による非音繁性アブミ骨筋 反射域涟は $10 \mathrm{~mA} て ゙ あ り ， 1 \mathrm{kHz}$ 音響性アブミ骨筋

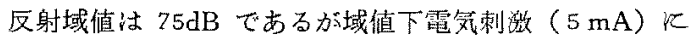
域值下咅響刺激（70dB）を同時仁与えると反応波形が認 められる（a）。をた域值上音繁刺激 $(80 \mathrm{~dB}, 85 \mathrm{~dB})$ を

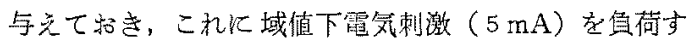
ると音㸷性アブミ骨筋反射に相乘して電気刺激による反

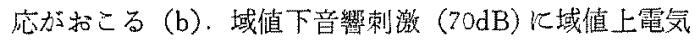
刺激 $(20 \mathrm{~mA})$ を同時飞真荷すると域値上電気刺激 $(20$ $\mathrm{mA}$ ) 単独の反応波班上り屯大きな振幅を得られること がわかった (c). 域値上電気刺激 $(20 \mathrm{~mA})$ と域值上音 響制激 $(80 \mathrm{~dB})$ の同持負荷で当然, 两者の反心波形の 組合せが認められるが，電気刺激による反店波形仕それ 単独のむのよりも大きな振幅であった（d）.

3. 反対側外耳道雷気刺湤によるアブミ骨筇反射の測定 外耳道電気刺激を利用した非音響性アブミ骨筋反射が 両側性に菍起されるかどうかれついて検討を行なった。 P.F. $25 \mathrm{~Hz}$, P. D. $0.01 \mathrm{msec}$ の電気刺激を使用し, 刺激

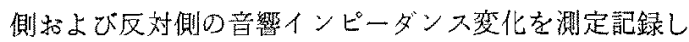
た. 結果は図9に示すごとく中等度以上の刺濑強度に対 して両側の筇反射反忘が得られたが，反応振幅を比較す ると刺洀側よりも反対側が小さい傾向にあった。 

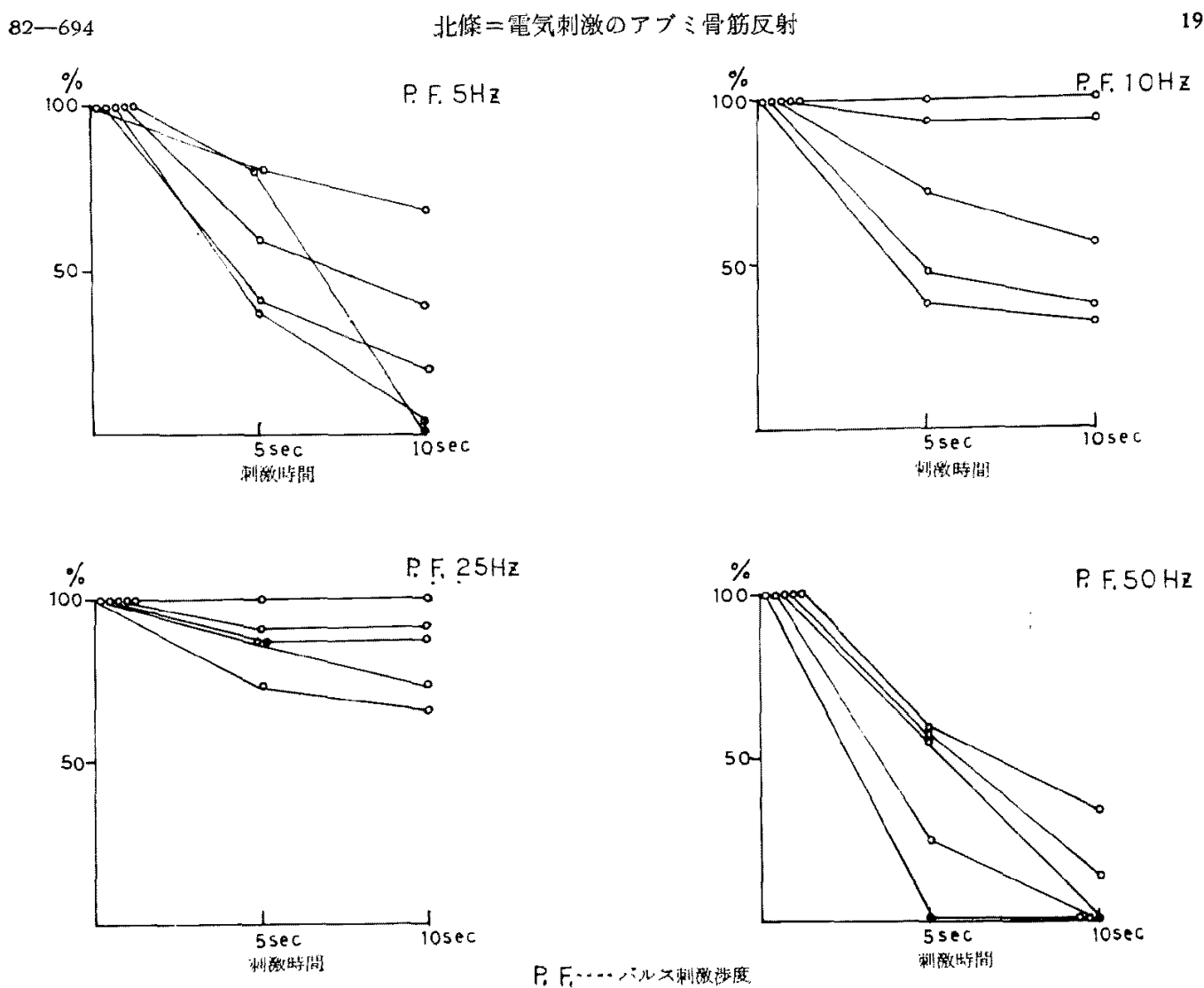

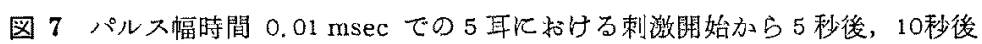
の振幅の減衰程度
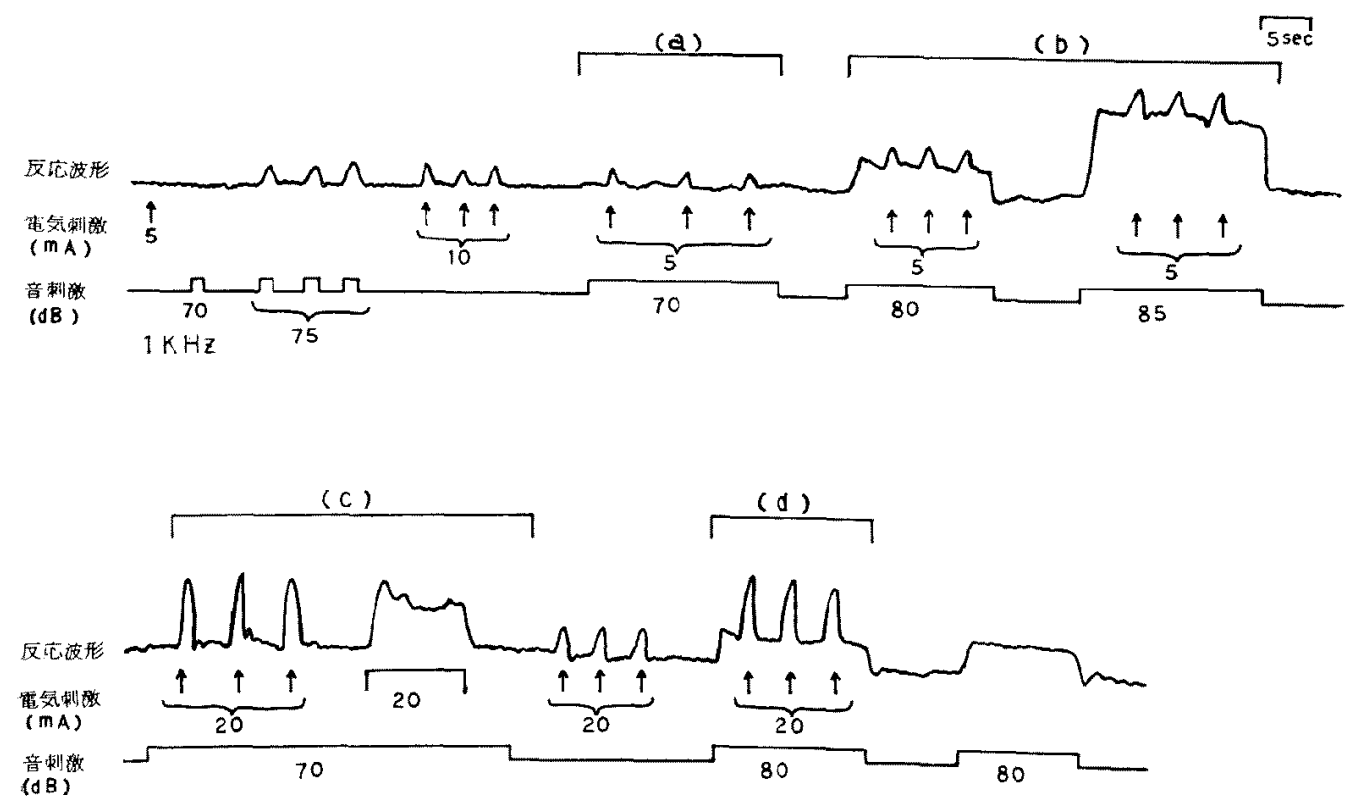

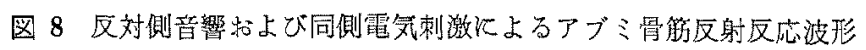



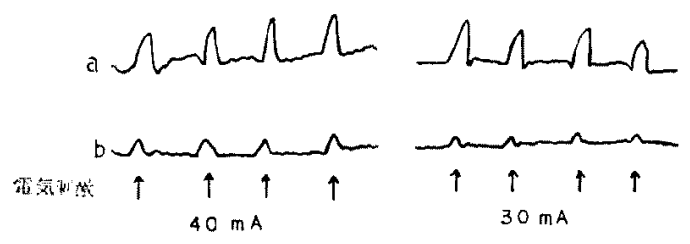

$$
\begin{aligned}
& \text { a...... 间明籿 }
\end{aligned}
$$

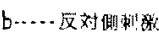

図 9 同側和よび反対側電気刺激によるアブミ骨䍌反射反忘波形

\section{4. 臨床例}

電気刺激法これまでの基礎的 Data より最適刺激条件 として P.F. $25 \mathrm{~Hz}$, P.D. $0.01 \mathrm{msec} の$ 矩形波パルズを 使用した。

\section{1）感音難㯖}

SISI テスト，Bekesy 検査，音響性アブミ骨筋反射測 定等の検查で両側内耳性難聴々診断された6例について， すべての症例で電気刺激に上る筋反射反応が貺定可能で あった，反射域值，中等度域值拉よび不快域值は正常者 のそれらとほほ同様の值であった（表 2).

2）末梢性顔面神経麻疸

ベル麻㿉 3 例, ハント症侯群 2 例, 外傷性麻瘦 2 例, 部 7 例飞ついて電気刺激による筋反射反応および音響性 アブミ骨筋反射の有䒜との関倸を比較した，表 3 亿示す

表 2 感音難聴耳の外耳道電気刺激佀よる各域值

\begin{tabular}{ccccl}
\hline 症 & 例 & 反射域値 & 中等度域値 & 不快域伹 \\
\hline Y.K. & 右 & $15 \mathrm{~mA}$ & $25 \mathrm{~mA}$ & $40 \mathrm{~mA}$ \\
& 左 & 15 & 25 & 35 \\
H.R. & 右 & 15 & 25 & 40 \\
& 左 & 10 & 35 & 45 \\
K.S. & 右 & 10 & 25 & 40 \\
& 左 & 7.5 & 25 & 40 \\
K.M. & 右 & 20 & 35 & 45 \\
& 左 & 15 & 25 & 35 \\
N. T. & 右 & 15 & 30 & 40 \\
& 左 & 15 & 30 & 40 \\
S.Y. . 右 & 15 & 30 & 45 \\
& 左 & 20 & 30 & 40 \\
\hline \multirow{2}{*}{ 平 均 } & & 14.38 & 28.3 & 40.4 \\
\hline
\end{tabular}

ごとくこれらの症例の中で音響性アブミ骨筋反射の認め られない，すなわち suprastapedial lesion の3例では 電気刺激を不快域値まで上げても反応波形は検出されな かった，健側耳に和いては正常者之はは同じ射域值， 中等度域值括よび不快域值で筋反射反応を検出できた。

3) 耳硬化症

手術的に確認された耳硬化症では，術前の音響性アブ ミ骨筋反射性最大音響宜荷 (120dB) で㮔出されなか った. 外耳道電気刺激法によって子不快域值まで刺激強 度を上げたが，筋反射反応はまったく出現しなかった (図 10)
4）一側高度難聴

表 3 末梢性顔面神経麻㽻症例の外耳道電気制 激と音響性アブミ骨筋反射の有無

症例 病名 反射域值 中等域值 不快域值 ASR

H.Y. 左ベル 右 $15 \mathrm{~mA} 30 \mathrm{~mA} 40 \mathrm{~mA} \quad(+)$

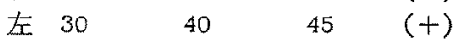

T. H. 左外傷 右 $15 \quad 25 \quad 35 \quad(-)$

左 $45 \mathrm{~mA}$ て scale out $(+)$

K. S. 左ハント右 $7.5 \quad 30 \quad 40 \quad(+)$ 左 $15 \quad 30 \quad 40 \quad(t)$

N. T. 右ベル 右 $40 \mathrm{~mA}$ で scale out (t)

左 $10 \quad 25 \quad 30 \quad(-)$

K.M. 左外䈓 右 $\begin{array}{llll}15 & 30 & 40 & (+)\end{array}$ $\begin{array}{lllll}\text { 左 } & 7.5 & 20 & 30 & (+)\end{array}$

Y.M. 右ベル 在 $10 \quad 30 \quad 35 \quad(+)$ $\begin{array}{lllll}\text { 左 } 10 \quad 20 & 40 \quad(+)\end{array}$

S. T. 右ハント右 $15 \quad 30 \quad 45 \quad(-)$ 左 $45 \mathrm{~mA}$ て scale out (t)

ASR…音響性アブミ骨筋反射 


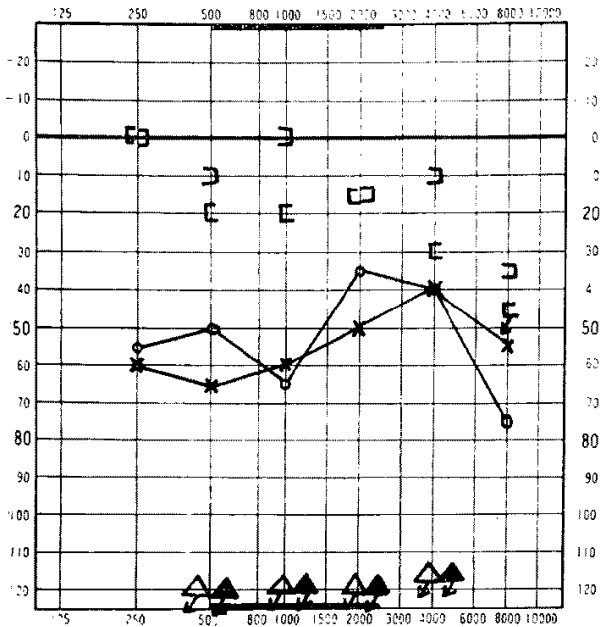

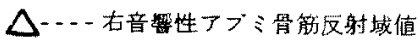

A… E音整性アプ令骨筋反射域値

外耳道電気刺敫

$\left.\begin{array}{l}\text { 右 } \\ \text { 左 }\end{array}\right\} 40 \mathrm{~mA} \tau(-)$

図 10 耳硬化症 8 40歳

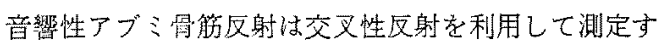
る場合，音刺激側江伝音難㯖や高度感音難㯖が存在する

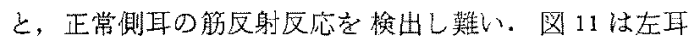
会話音域正常, 石耳ううの淀例であるが, 左耳の音㗽性 アブミ骨筋反射は右耳儿鼠高音圧 $120 \mathrm{~dB}$ 劣与光ても榆 出できず，左耳のアブミ冎领機能については不明である。

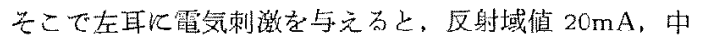
等度域值 $30 \mathrm{~mA}$ ，不快域值 $40 \mathrm{~mA}$ て筋反射反応を明瞭 に椧出できた，な放，ろうである右耳のアブミ骨筋反射 は左耳の音刺激战よび右耳の電気刺激伛よっても認めら 扎ている。

5）両側高度蜼聴

図 12 の症例の場合，左右とも音䡚性アブミ骨筋反射 は梌出困難でありアブミ胃觔の機能は不明である。しか しそれぞれの耳に雪気刺激を与文ることにより左右と も，正常者上ほほ同様の域值で筋反射反応を検出てき ז.

6）小脳橋角部随演

手術的火確認された 2 症例と CT にて疑われた 1 症

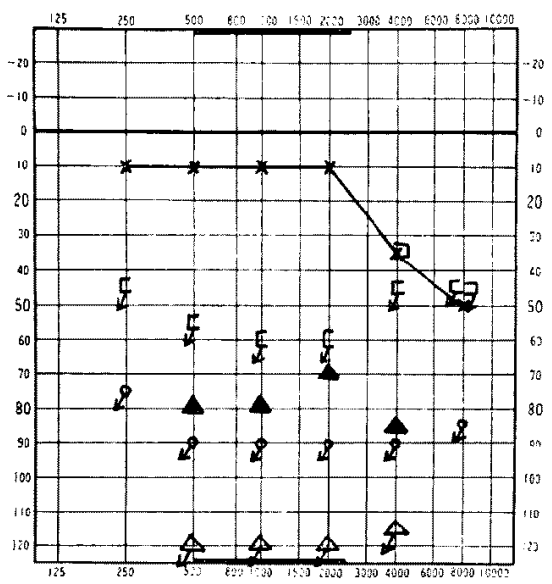

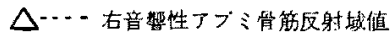

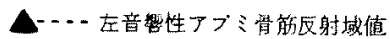

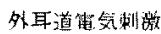

\begin{tabular}{|c|c|c|c|}
\hline & 反射域优 & 中等管域值 & 不秋城储 \\
\hline 石 & $15 \mathrm{~mA}$ & $30 \mathrm{~mA}$ & $40 \mathrm{~mA}$ \\
\hline Ex & $20 \mathrm{~mA}$ & $30 \mathrm{~mA}$ & $40 \mathrm{~mA}$ \\
\hline
\end{tabular}

図 11 一側高度難德 $\delta 41$ 歳

例について検討した。

i）右复神経随瘍（図 13）

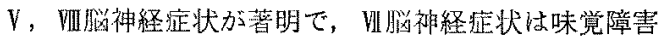
のみであった，慗側（右耳）の音響性アブミ具筇反射は 0.5, $1 \mathrm{kHz}$ にて $100 \mathrm{~dB} て ゙ \mathrm{~m}$ 定でも淂性の所見であった，左笛響性アブミ骨筋反射は 正常领明に出現している。霓気刺激では患侧(右耳)で

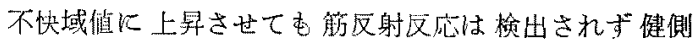
(左耳)では正常域做笵四にて検出された。後頭下開頭

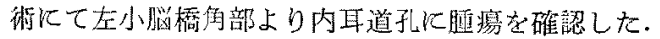

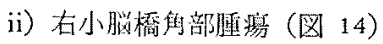

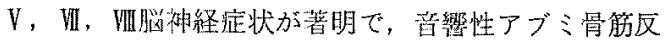

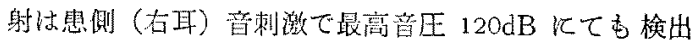

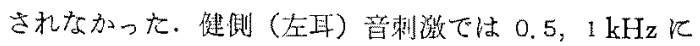

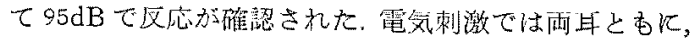

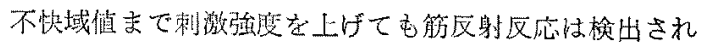

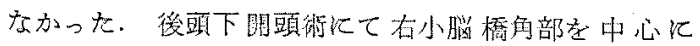

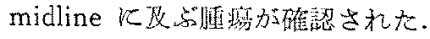

iii）左聪棚経脽疼口疑い（因 15） 


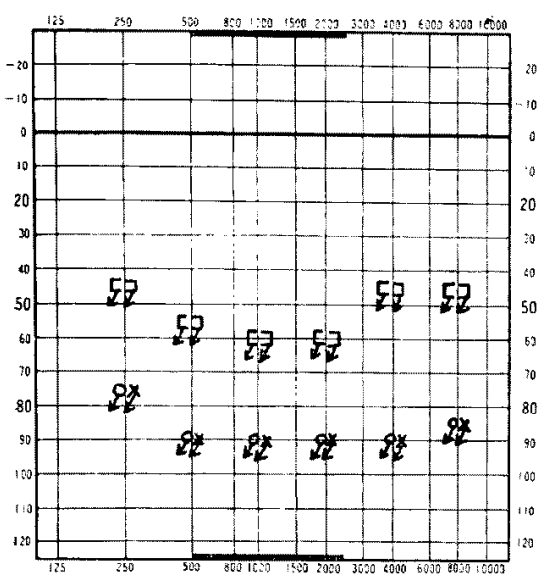

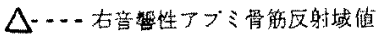

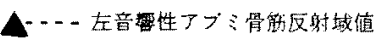

外耳道篧気刺要

\begin{tabular}{l|l|l|l|} 
& 又射城缩 & 中等度城值 & 不快域犆 \\
\hline 古 & $15 \mathrm{~mA}$ & $30 \mathrm{~mA}$ & $40 \mathrm{~mA}$ \\
\hline 左 & $20 \mathrm{~mA}$ & $30 \mathrm{~mA}$ & $40 \mathrm{~mA}$
\end{tabular}

图 12 雨偩高度難聴 657 歳

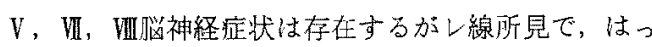
きりした内耳道の桩大はみられず CTにて左小脳橋角

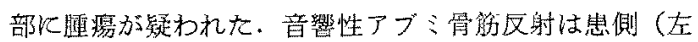
耳）音剌激で最高音圧 $120 \mathrm{~dB}$ にても湌出されず，また

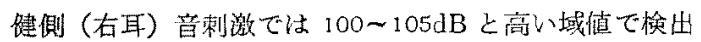
された。電気刺激では侓側（右耳）でほぼ正常域值にて

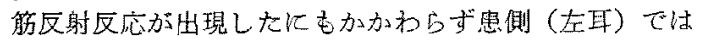

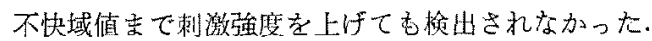

\section{IV 若 案}

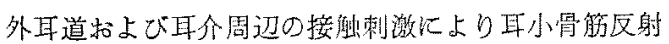

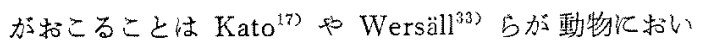

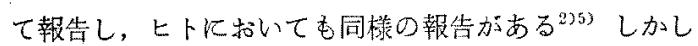
ながら，インピーダンスメータを使用する場合，接触剌 激法では耳栓化触れてアーチファクトを発生させ万危陨

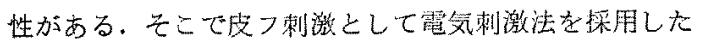
加，丁一チファクト発生防止以外飞, 刺激㩖を一定に, しかも定量化すること加でるるよ゙の利点もある。さて 外耳渞電気刺激により落起されたインピーダンス整化が

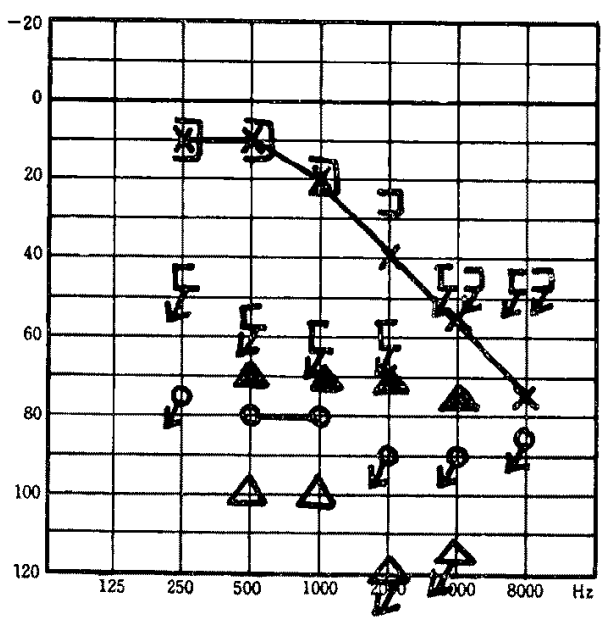

図 13 右聴神経連㴏 569 歳

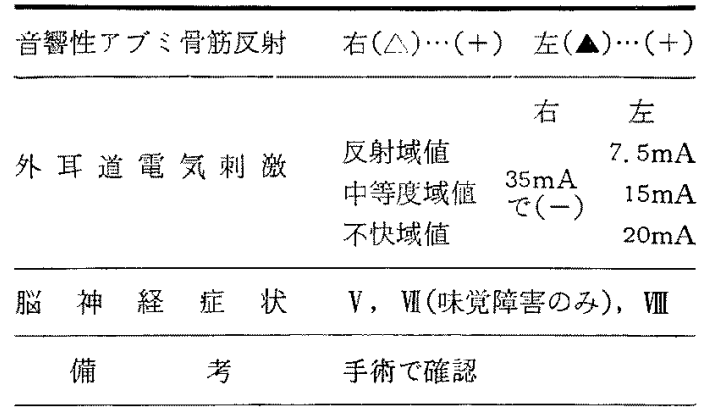

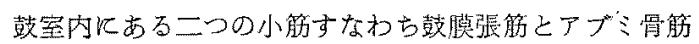
のうち，いずれの筋による作用であるかといらことが問 題上なる. Klockhoff ${ }^{18)}$ Kよれば 1) 手術的飞磼認さ れた中耳伝管障害例，2）アブミ胃節揵切断例，3）末

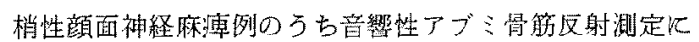
よりアブミ等麻樌の認められた症例ではいずれも外耳 道電気剌激によるインピーダンス变化が测定されなかっ

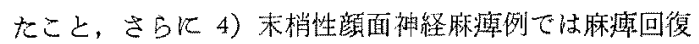

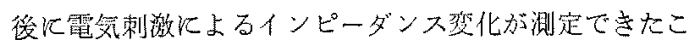

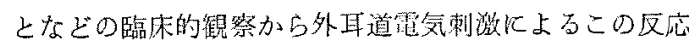
はアブミ骨筋の作用であるとした. Yonovitz ら は外

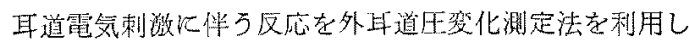
て挌こない，アブミ骨摘出症例では，何方变化のなかっ

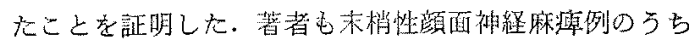

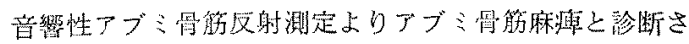
れた症例，手術的飞耳硬化症上碓珰された症例の術前检 查で電気欶激によってもインピーダンス变化がまったく 


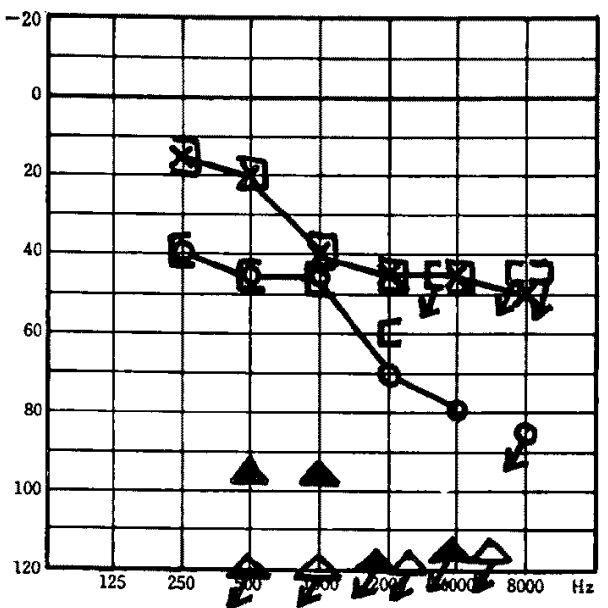

図 14 右小脳橋角部腫㾨 +76 歳

\begin{tabular}{|c|c|c|c|}
\hline \multirow[t]{2}{*}{ 音響性アブミ骨筇反射 } & \multirow[t]{2}{*}{ 右 $(\Delta) \cdots(-)$} & \multicolumn{2}{|c|}{ 左(A) $\cdots(+)$} \\
\hline & & 右 & te \\
\hline 外耳道電気搉激 & $\begin{array}{l}\text { 反射域值 } \\
\text { 中等度域值 } \\
\text { 不快域值 }\end{array}$ & $\begin{array}{l}45 \mathrm{~mA} \\
\tau(-)\end{array}$ & $\begin{array}{l}\frac{45 \mathrm{~mA}}{\tau^{2}(-)} \\
\end{array}$ \\
\hline
\end{tabular}

脳 神経 症 状 $\mathrm{V}, \mathrm{II}$, 䜣

蒈考術で確認

認められなかったことより，この変化はアブミ骨筇が主 役を演じていると推諭せざるをえない。

電気刺激の種類には定電王刺激法と定電流刺激法と加 ある. Klockhoff ${ }^{\text {む) }}$ 访定電压刺激法を用いたが制激時間

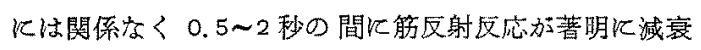
していく、いわゆる㮌応理象を認め, Yonovitz $5^{342}$ 同様の報告をしている．著者の使用した定電流刺激法で は後に述べごとく，この順応現象がきわめて少なかっ た. このことは電気生理学的に定電流刺激では定電生刺

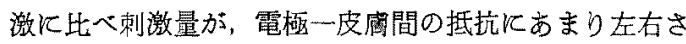
れず，電極に多少の脱分極が生じていても一定の刺激量 を得ることができること，さらに今回使用した $\mathrm{Ag} / \mathrm{AgCl}$ 電極加他の金属電極と比較し分極電圧の值吕極端に小さ く，不分極電極といわれて扣り刺激電極として理想的て あること 22303などの理由にもとづくものと考えられる。

次に外耳道電気刺激に上る非音響性アブミ骨筇反射を 臨床に応用する場合，問題となること被験者への疼痛

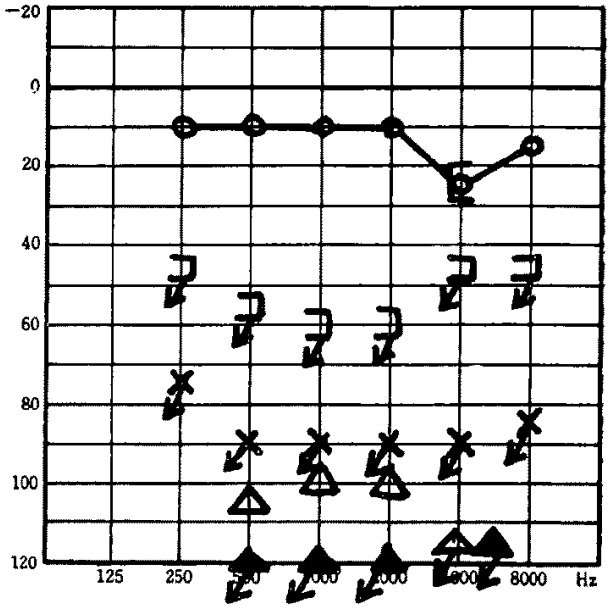

図 15 左㯖神経腫崲の疑い今 41 葴

\begin{tabular}{|c|c|c|c|}
\hline 音響性アブミ骨筇反射 & 右 $(\triangle) \cdots(+)$ & \multicolumn{2}{|c|}{ 左 $(\mathbf{A}) \cdots(-)$} \\
\hline & & 右 & 左 \\
\hline 外耳渞需穵刺激 & 反射域值 & $10 \mathrm{~mA}$ & \\
\hline & 中等度域倠 & $15 \mathrm{~mA}$ & $\begin{array}{l}40 \mathrm{~mA} \\
\tau(-)\end{array}$ \\
\hline & 不快域值 & $30 \mathrm{~mA}$ & \\
\hline
\end{tabular}

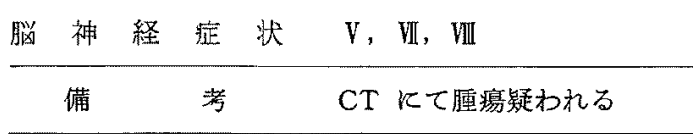

等の不快感をできるだけ少なくし，反応振幅が比較的大 きく，乙かす順応現象の㒛められない再現性のある筋反 射反応をい加得るかということである。今回，これら の点について電気刺激のパラメータのうち P.F., P.D. そして刺激強度との関係を検討し最適刺激条件を求めた わげである.P.D. K夙しては短くすればするはこ反射 域值と不快域值の間滆が広くなることが判明した。すな わち P.D. $0.01 \mathrm{msec} て ゙ は$ 感賞域值, 反射域值, 中等度 域侱叔よび不快域值差が他の P.D. $1 \mathrm{msec}, 0.1 \mathrm{msec}$

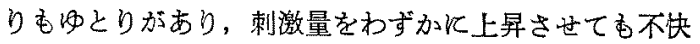
感省生ずる危険性がない。そこで P.D. $0.01 \mathrm{msec}$ 飞拈 ける P.F.の影響を10秒間刺激による順応現象との関係 について検討を行ない，P.F、25Hzで最す少ないことが

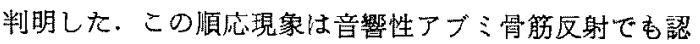
められたごとくアブミ骨笳の側基因するものでなく求

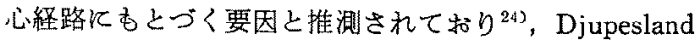

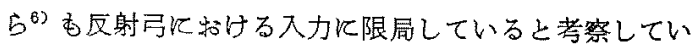


る、な呿反応浱幅は一般に，制激強度の增扣飞伴い大き くなる傾向が認められており，P.D. $0.01 \mathrm{msec} の$ 条件 では中程度域值 よびび不快域值飞执いて P.F. $25 \mathrm{~Hz}$, $50 \mathrm{~Hz}$ が大きな振幅を示した.

以上, 今回の測定結果よ b P.F. $25 \mathrm{~Hz} ，$ P. D. 0.01 msec の電気刺激が 1) 不快感を起こしKくいこと 2) 順応現象驾少ないこと. そして 3）他の条件と比較し，

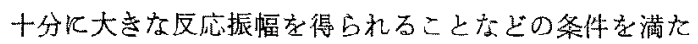
し最適と考えた。これらのうち，疼痛等の不快感付対し ては特飞 P.D. が，順応現象に対しては特飞P.F. が関 与しているように思われる。刺激条件の規準化に関して は Klockhoff ${ }^{(8)}$, Djupesland $5^{62}$ によってもなされて いるが, Klockhoff は P. F. $50 \mathrm{~Hz}$, P.D. $1 \mathrm{msec}$ の定電 代刺激を，Djupesland 5法 P.F. $200 \mathrm{~Hz}$, P.D. $1 \mathrm{msec}$ の定電流刺激を刺激時間 0.5 秒で 10 秒間隔にて与えるこ とを推奖している、しかしながら前者の力法ては前述し たごとく順応現象が生じやすい欠点があり，また後者の 方法性不快感付対してあまり注意を払わず順応現象の最 屯少ないできるだけ大きな筋反射反応党得ることに基準

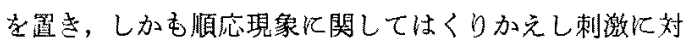
してのみ検討しているだけで持綕的な刺激沉ついては娭 討していない，さて P.F. $25 \mathrm{~Hz}$, P.D. $0.01 \mathrm{msec} の$ 電 気刺激任抬ける反射域值は 9 15mA (平均 $13 \mathrm{~mA}$ ), 中 等度域值は 20 30mA（平均 $25 \mathrm{~mA}$ ), 不快域值は 30 $45 \mathrm{~mA}$ (平均 $38 \mathrm{~mA}$ ) であり，各個人間佂正常人であか なりのバラッキを認めた。この原因として外耳道内に扔 ける刺激電極の位置や皮庵抵抗などの相䧺が考えられて いる. Klockhoff ${ }^{19)}$ 飞上れは外耳道の前, 捘, 上, 下の 各部位によって電気制激に対する感受性に差のあること が指摘されて招り，彼の力法では後壁加ら最む低い刺激 強度で筋反射反応が測定されたという.今回の私の実験 では外耳道後上壁の刺激汇上り反射域值, 振幅とをに最 良の結果が得られているが，Djupesland ら 腔刺激法を利用している.いずれにせ上電気刺激測定法 の場合，刺激部位牥留意すべき点の一つである、また中 等度域值括上び不快域值は被験者の主観に上ってきまる あのであるため，ある程度のバラッキはやむを得ない。

電気扣よび音の同時刺激による筋反射反応は生理学的 て興味のある所見を示した。すなわち反対側耳音響性 アブミ骨筋反射域值下の音刺激を与えると区射域值下電 気刺激でも筇反射反応が観察された。ささら飞反射域值上 ある程度の強さの電気刺激による筋反射反芯は域值下な い儿域値上の音刺激を气えと電気制激単独の場合上り
もその振幅が增大した．このことについて Klockhoff ${ }^{16)}$

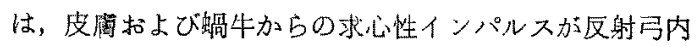
で同一の連動神経の反射発火に関与しているためである うと若察している.

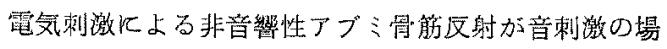

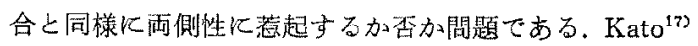

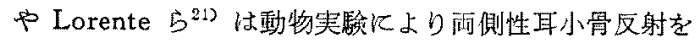
報告しているが，七トに拾ける報告はな怙区及である。

Pichler $5^{293}$ は外耳道電気刺激により刺激側耳で $1 \mathrm{kHz}$

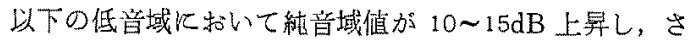
らに反対側耳でも約 $5 \mathrm{~dB}$ 以内の上曻を諗め，これは一

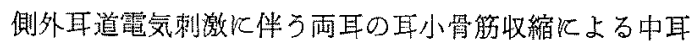
伝音能率の変化によるものとした. Djupesland 社耳介

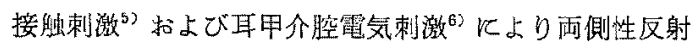
収縮をインピーダンスメータにて記録し，また測定側耳 のアブミ骨筋反射を反対側耳の接蚛刺激により筋掣図学 的 ${ }^{2)}$ 飞它証明した，し加しKlockhoff ${ }^{18)}$ はこの反射を雨 側性でないと結諭した，その理由として刺激强度を强め ると不快感のため眼輪筋收縮が朽こり, それ伴う反応 であるとした，著者は中等度以上の電気刺激強度により 雨側性汇筋反射反忘を明らかに記録できた。この時の被 験者の状態を仔細観祭してみると，表情筋枋よび体動 等のアーチファクトはまったく認められず，外耳道電気 刺激によるアブミ胃筋反射は音刺激と同様汇雨側性反応 であると考光る。

非音翼性アブミ骨筋反射局については不明な点が多い

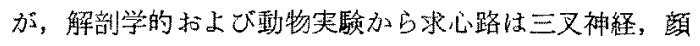
面神経の中間神経, 舌因神経, 氹走神経扰よび澒䯣 $\left(\mathrm{C}_{2}\right.$, $\mathrm{C}_{3}$ ）の知党枝が考えられ，又射中枢は脳幹部存在し， 遠心路は顔面神経一アブミ骨筋であると推湘されている

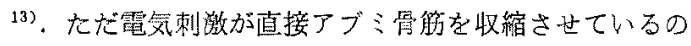
ではないかという態念もあるが，外耳道が麻酔された場 合飞は筋反射は認められていない: ${ }^{18228)}$. 今回の臨休例の うち末梢性顔面神経麻㾴例から，遠心路炕関してはまち がいないものと考元るが求心路他ついては，小脳橋角部

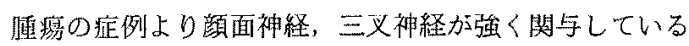
あのと思われた. 今後, この方面の害験的, 臨床的研究 がまた机る。

\section{$\mathbf{V}$ 結 語}

1) 外耳道電気刺激により得られた音響インピーダンス 変化は考案で述べたごとく故膜張筋の作用ではなくアブ ミ骨筋收縮几上るものと推測された。 


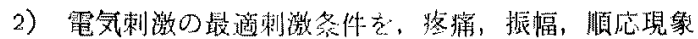
などの面より検討し，パルス腷恃閒 $0.01 \mathrm{msec，パルス}$ 頻度 $25 \mathrm{~Hz}$ の定電流然形波パルスが最阗であった：その 反射域值は平均 $13 \mathrm{~mA}$, 不扷域值仙平均 $38 \mathrm{~mA}$ であっ た.

3) 反射域值下の皆刺激执よび電気刺溦を同時比与える と筋反射反㐫を検出できた。 また反射域值下および域俌 上の篦刺激真荷する上電気刺激单独の反応波形上り振 楅の大き波班が得られた。

4）中等度以上の外耳道電罙刺激強度て両㑡性沉筋反射 反応が観祭されたが，刺激側飞比へ反対側は反志振幅が 小さ加长。

5）外耳道電気刺激による非音望性アブミ骨筇反射湘定 はインピーダンスオージオタトリ一の一分野に和ける重 要な㭘查法と思すれる。

\section{考文献}

1) Anderson et al.: Early diagnosis of VIIIth-nerve tumors by acoustic reflex. Acta Oto-laryngol., 263: 232-237, 1970 .

2) Djupesland G.. Electromyography of the tympanic muscles in man. Audiology 4:34-41, 1965.

3) Djopesland $G$, Observation of changes in the acoustic impedance of the ear as an aid to the diagnosis of paralysis of the stapedius muscle. Acta Otolaryngol., 68: 1-5, 1969.

4) Djupesland G.: Middle ear muscle reflexes elicited by acoustic and nonacoustic stimulation. Acta Otolaryngol, Suppl. 188, 1963.

5) Djupesland G.: Contraction of the tympanic muscles in man. Universitetsforlaget, Oslo. 1967. Cited by Djupesland, G. (1977).

6) Djupesland $G$, Flottrop $G$ and Sundby $A$. Impedance changes elicited by electrocutaneous stimulation. Audiology 16: 355-364, 1977.

7) Greisen $O$, et al.: Stapedius muscle reflexes and Otoneurological examinations in brain stem tumors. Acta Otolaryngol., 70: 366-370, 1970.

8) Gunn WJ.: Loudness changes resulting from an electrically induced middle-ear reflex. J.A.S.A. 54: 380-385, 1973 .

9）北条和博 他：外耳渞電気胡激に上るアブミ骨笳反 射の测定 Audiology Japan, 18: 283-289, 1975.
10) 北条和塗 他：Metz-test (ABLB-est, SISI-test, Bekesy-test との比较) Audiology Japan, 20: 27$32,1977$.

11) Jerger $E$, et al.: Diagnostic value of crossed VS uncrossed acoustic reflexes. Arch. Otolaryngol., 103: 445-453, 1977.

12) Jerger J.: Clinical experience with impedance audiometry. Arch. Otolaryngol., 92: 311-324, 1970.

13) Jerger $J_{.}$: Handbook of Clinical impedance audiometry. New York, American electromedical corporation, 1975.

14) Jerger $J$, et al. The acoustic reflex in eighth nerve disorders. Arch. Otolaryngol., 99: 409$414,1974$.

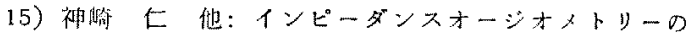
蹈床的応用。耳㬋., 45: 1009-1019，1973.

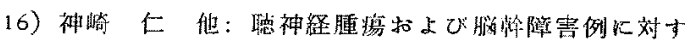

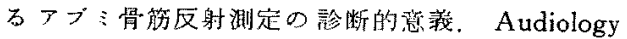
Japan, 20: 103-109, 1977.

17) Kato T.: Zur Physiology der Binnenmuskeln des Ohres. Pfluig. Arch. ges. Physiol,, 150; 569$625,1913$.

18) Klockhoff I.: Middle ear muscle reflexes in man, Acta Otolaryngol., Suppl. 164, 1961.

19) Kristensen $H K$ and Jepson $O$.: Recruitment in otoneurological diagnostics. Acta Oto-laryngol., 42: 553-560, 1952.

20) Lamb LE, et al.: Application of stapedius muscle reflex measures to diagnosis of auditory problems. Audiology, 7: 188-199, 1968.

21) Lorente de No.R.: The reflex contraction of the muscles of the middle ear as a hearing test in experimental animals. Trans. amer. laryng. rhin. otol. soc. 39: 26, 1933. Cited by Klockhoff, I. (1961).

22）松尾正之他：生体用金属電極の電烰的特性。医朋 電子と生体工学 8：151-159，1970.

23) Metz O.: Threshold of reflex contractions of muscles of middle ear and recruitment of loudnee. Arch. Otolaryngol., 55: 536-543, 1952.

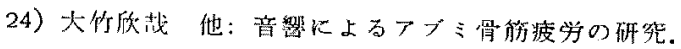
Audiology Japan, 16:215-216, 1973. 
25）大竹欣裁 他: インピーダンスオージオメトリーの 臨休応用。日耳舞 77 : 183-198，1974。

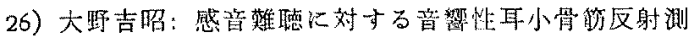
定の鶜断的意義. Audiology Japan, 13: 283, 1970.

27）大野吉昭：音整性アブミ骨脖反射の备唒バラィータ 一の测定上絪幹障害例の分析。第79回日耳鼻シンポ ジウム別册， 1978.

28) Ohno $Y$, Nagel $D$ und Pfalz R.: Stapedius Reflex des Menschen bei Ipsilateraler elektrischer Reizung im Gehörgang. Die Arbeitsgemeinschaft Deutscher Audiologen und Neurologen. (ADANO) 1977.

29) Pichler $H$ und Bornschein $H$.: Audiometrischer Nachweis nicht akustisch ausgelöster Reflexkontraktion der Intraauralmuskulatur. Acta Otolaryngol., 48: 498-503, 1957.

30）四頭 功他：生体用金㻕電極の交流特性选用電 子と生体工学 10：222-230, 1972 .

31) Thomsen $J$, et al.: Audiological findings in 125 cases of acoustic neuromas. Acta Oto-laryngol., 80: $353-361,1975$.

32) Thomsen $K A$.. The metz recruitment test. Acta Oto-laryngol., 45: 544-552, 1952.

33) Wersäll R.: The tympanic muscles and their reflexes. Acta Otolaryngol., Suppl. 139, 1958.

34) Yonovitz $A$ and Harris $J D$.: Eardrum displacement following stapedius muscle contraction. Acta Otolaryngol., 81: 1-15, 1976

稿を終るにあたり，御指導，御校閶定賜った恩師猪初 男教授飞深謝いたします。また研究の直接御指尊学いた

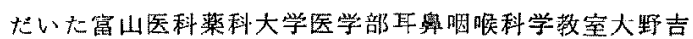

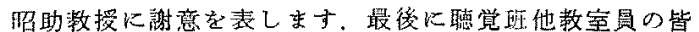
煫に感腤いたします。

(滰稿受付 昭和54，4，26日急使)

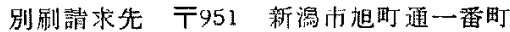

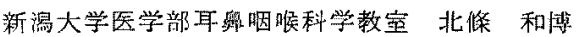

